\title{
Trajetórias de Multinotabilidades: Reconfigurações Históricas e Condicionantes Sociais das Inscrições Políticas e Culturais de Parlamentares Brasileiros
}

\author{
Eliana Tavares dos Reis ${ }^{1}$ \\ Igor Gastal Grill ${ }^{2}$ \\ ${ }^{1}$ Universidade Federal do Maranhão (UFMA), São Luís, MA, Brasil. E-mail: \\ eliana1reis@terra.com.br \\ ${ }^{2}$ Universidade Federal do Maranhão (UFMA), São Luís, MA, Brasil. E-mail: \\ igorgrill@terra.com.br
}

\section{APRESENTAÇÃO}

1 o espaço social mais amplo, o acesso a determinados conhecimundo prático, não reflexivo, pragmático, ordinário) legitima posições de poder, sedimentando reputações distintivas em e entre diversos segmentos de grupos dominantes (jurídicos, midiáticos, religiosos, universitários etc.). Particularmente no universo político, observa-se a associação corrente à capacidade de uso da "palavra" (escrita e oral) como recurso de entrada e trunfo contundente para a construção de carreiras.

Há uma extensa bibliografia produzida por cientistas sociais brasileiros nas últimas décadas sobre carreiras e perfis de políticos. Grosso modo, a literatura - a despeito das divergências entre os autores que adotam ênfases mais societais, organizacionais, de caráter mais objetivista ou perspectivista - lança luzes sobre os padrões de institucionalização dos partidos brasileiros ${ }^{1}$, as clivagens partidárias e o recrutamento/seleção política ${ }^{2}$. A noção de carreira aqui utilizada é relacionada aos desdobramentos das apostas feitas por agentes políticos desde suas entradas na política (Offerlé, 1996), procurando apreender as modificações nos princípios de aferição de excelência humana e a sua reconversão em critérios de hierarquização política e intelectual, bem como as gramáticas que fixam complementaridades entre os domínios políticos e culturais em distintas conjunturas.

DADOS - Revista de Ciências Sociais, Rio de Janeiro, vol. 58, n-2, 2015, pp. 331 a 369.

http://dx.doi.org/10.1590/00115258201546 
A questão que se coloca neste artigo é: como, no trabalho político e cultural, "arte de escrever" e "vocação para representar" sintetizam um duplo e indissociado reconhecimento instituído na inscrição em domínios concorrenciais de atuação e na autoridade reivindicada/atribuída para definir e agir sobre o mundo social? Ou seja, no universo em pauta os agentes estão, a um só golpe, autorizados, por delegação instituída, a tomar decisões políticas em arenas públicas, com pleno poder de ação e direito de preempção (Bourdieu, 1984); e, no mesmo grau, contam com o reconhecimento (não adstrito às certificações dos meios políticos, mas também culturais) da sua autoridade para dizer (produzindo então representações) o que é ou deveria ser o "Estado", a "sociedade", a "economia", a "cultura" etc.

A oportunidade de conquistar tal reconhecimento é dada por uma dinâmica em que a politização sintetiza processos que interseccionam diferentes vias, como aquela que diz respeito ao descolamento histórico de uma esfera especializada de exercício da atividade política (no sentido weberiano); outra relacionada aos discursos, às vezes estruturados em jargões de uma moral cívica que retoma a filosofia política para consagrar o aprendizado da "participação" e o "interesse dos cidadãos por política"; e a politização da vida social que, em contextos como o brasileiro, abrange a importação e a redefinição das duas anteriores, resultando em arranjos nos quais as disposições políticas e os posicionamentos sobre temáticas políticas ou politizáveis são gerados no amalgamento de registros e práticas ambivalentes (morais, culturais, burocráticas, sociais, éticas, estéticas etc.). Isso, quando associado à concentração e uso de determinados recursos que efetivamente contam (principalmente de origens sociais, títulos escolares e redes de relações), colabora para a ocupação das posições as mais bem alocadas na hierarquia social como um todo e naquelas homólogas nos domínios sociais específicos (Reis e Grill, 2008).

Com efeito, se, por um lado, tem-se uma configuração histórica marcada por uma forte multidimensionalidade condicionada e condicionadora de práticas, sentidos e reconhecimentos, por outro, tem-se a possibilidade de apreensão de um sistema de posições, oposições e posicionamentos com a operacionalização de dimensões articuladas de análise, quais sejam: a origem social dos agentes; os instrumentos legítimos de expressão monopolizados; a visibilidade e reputações logradas; a encarnação de atributos de excepcionalidade valorizados; e a ra- 
tificação pelos aparatos de celebração e outros modos de autorização fundados em certificações institucionais.

Para os dois níveis acima (o primeiro de inspiração mais empírica e o segundo, analítica), sugere-se aqui uma ponte de mediação ou de síntese entre eles: a noção de multinotabilidade, cuja raiz encontra-se na definição weberiana do "notável" como sendo aquele que consegue converter a estima decorrente da sua origem social, da sua fortuna ou de recursos passíveis de serem distribuídos aos seus seguidores em posição de poder (Weber, 1987). Contudo, para o emprego atualizado da ideia de notabilidade, não se deve perder de vista, em primeiro lugar, que ele é parcial quando desconsidera a associação feita por Max Weber entre a figura do notável e a situação econômica específica dos indivíduos que ocupavam cargos eletivos sem necessidade de remuneração ("viviam para a política"). Em segundo, admite pensar como os notáveis de outrora se acomodaram à formação de uma elite política especializada, profissionalizada e às exigências de burocratização e modernização da política. Vale igualmente o oposto, isto é, como as novas gerações de políticos profissionais assimilaram formas "tradicionais" ou readaptadas de notabilização, num processo ininterrupto de interpenetrações e osmoses (Phelippeau, 2002; Grill, 2008). Noutra direção, pode-se perceber como mudanças mais gerais contribuem para a afirmação de "novos notáveis" 3 . Neste último caso, trata-se de agentes específicos que conseguem reunir e mobilizar suportes de reputação pessoal em domínios e lógicas específicos ou múltiplos.

O estudo das trajetórias de dois personagens da política brasileira no século XX - cujos meios e espaços de ingerência alimentaram um montante de recursos de intervenção de caráter multidimensional e de capitais simbólicos personificados - traz elementos que permitem testar pistas de investigação sob o registro das transformações históricas mais gerais, dos trunfos combinados em diferentes circuitos, assim como acerca da pertinência do arcabouço conceitual aplicado. São aqui analisados dois modelos de notabilização que se sucedem ao longo do tempo e se mesclam em personagens que desfrutam do duplo reconhecimento como intelectuais e políticos profissionalizados: Afonso Arinos e Delfim Netto. A escolha desses casos exemplares foi amparada na exploração sociográfica mais ampla que mapeou as propriedades sociais, carreiras políticas e gêneros de escrita para uma gama ampliada de parlamentares brasileiros com itinerários políticos relativamente bem-sucedidos (em termos de longevidade e de posição al- 
cançada na hierarquia de postos) e que se aplicam (ou se empenharam em algum momento) na produção e publicação de livros. Esboçou-se, assim, um espaço de relações de força entre agentes com certas características ou injunções necessárias à ocupação das posições dominantes (Grill e Reis, 2012).

Os dois protagonistas são políticos e intelectuais do "seu tempo". Examinando os períodos em que exerceram suas atividades de forma mais intensa e com notoriedade, verifica-se os investimentos que priorizaram na aquisição/explicitação de saberes, habilidades e lugares de atuação consonantes com seus recursos de origem e com as condições específicas de concorrência (perspectiva sincrônica). Porém, não foram somente protagonistas de "um tempo", pois seguiram rotas prolongadas cujos desdobramentos ensejam perceber quais lógicas e imposições agiram na inovação de estratégias e trunfos de afirmação, decorrentes de reconfigurações das exigências e das bases de reconhecimentos legítimos. Esta dinâmica de interdependências é revelada aqui na sequência dos respectivos trajetos (perspectiva diacrônica). Em tela, duas matrizes (política especializada e cultura erudita) que garantem posições variadas e relativamente bem assentadas em diversos domínios (parlamentar, universitário, midiático, burocracia de Estado, instâncias de consagração intelectual, lugares de formulação de políticas públicas, entre outros). E, por intermédio da construção dos percursos e assinalando as tomadas de posição, é possível situar, igualmente, processos, bases e linguagens de notabilização vigentes no Brasil ao longo do século XX.

\section{CARREIRAS POLÍTICAS E PRODUÇÃO ESCRITA}

Em uma pesquisa anterior, cuja fonte principal foi o Dicionário HistóricoBiográfico Brasileiro da Fundação Getulio Vargas (Abreu et al., 2001), foram localizados 1.181 agentes (deputados federais e senadores) que, em seu conjunto, registram por volta de 4.062 títulos de trabalhos classificados em diferentes gêneros de escrita: generalistas, setoriais, históricos, literários e (auto)biográficos. Nesta exploração preliminar, além da recorrência diferenciada dos próprios gêneros em termos numéricos, foram identificados o estado de origem e o período de atuação desses políticos no intervalo de 1945 a 2010 (Grill e Reis, 2012).

A convergência entre uma não negligenciável produção escrita (em termos de livros) e uma sólida regularidade na ocupação de cargos públicos e eletivos (captada pela duração das carreiras de cargos eletivos) 
foi o principal critério para proceder, naquela ocasião, à delimitação de 299 casos. Operou-se, para esses, correlações dos gêneros de escrita com as décadas de entrada na política, com os títulos escolares e profissionais conquistados e com a posição política galgada. Isto proporcionou de um modo geral, por um lado, a verificação dos contornos de uma "elite letrada e votada" no universo político (Grill e Reis, 2012; Reis e Grill, 2008) e, por outro, o estabelecimento de parâmetros para a escolha dos dois casos pertinentes à análise de trajetórias exemplares, alvo central deste artigo. Daquela incursão exploratória, algumas constatações gerais podem ser retomadas.

Sobre a periodização, por exemplo, foi verificada a tendência histórica ao aumento de escritos sobre temáticas especializadas, que exigem saberes técnicos específicos; a diminuição das publicações dedicadas à consagração de heróis, personalidades políticas, eventos históricos julgados singulares, bem como da produção de textos mais literários (como poesias, crônicas, novelas, romances etc.); e a persistência das preocupações gerais, que tratam de grandes questões, projetos de sociedade, destinos sociais e coletivos, pensam determinada região e seguem um viés mais ideológico, ou, mesmo, moral.

Outra tendência que chamou a atenção, agora concernente aos títulos escolares e profissionais, foi a da existência de uma clivagem entre, por um lado, um padrão que associa saberes técnicos com o gênero setorial e, por outro, um que mobiliza conhecimento em "humanidades" com o tipo "generalista".

No que se refere às correlações com carreiras políticas, algumas recorrências também podem ser sublinhadas. Quando tomamos o cargo político mais alto ocupado, observamos, entre outras coisas, que aqueles agentes que foram no máximo deputados federais escrevem sobre temas mais especializados, numa propensão crescente à produção de caráter mais técnico ou setorializado; ao passo que aqueles que conquistaram governos de Estado e cadeiras no Senado da República tendem a seguir ocupando-se de generalidades (grandes temáticas sociais e políticas) e publicando biografias históricas, colocando-se, por esse intermédio, a serviço da memória política, dos seus vultos e ícones. Este dado é reforçado quando se correlaciona os gêneros de escrita privilegiados com informações sobre o tempo dedicado a mandatos eletivos e a cargos político-administrativos. Evidenciou-se, pois, que parlamentares com carreiras predominantemente eletivas escrevem mais sobre 
generalidades e literatura, acionando menos os saberes especializados, enquanto aqueles que combinam cargos eletivos e administrativos ao longo de suas carreiras fazem o contrário, ou seja, têm inclinação para escrever mais sobre temas especializados e menos sobre literatura e generalidades. Já os senadores e deputados que ocupam principalmente cargos administrativos, dedicam-se prioritariamente à produção setorializada.

Afonso Arinos e Delfim Netto representam casos modelares dessas tendências e a construção das suas trajetórias propicia delinear de forma dinâmica os processos e condicionantes das práticas e lógicas dominantes em distintas conjunturas históricas que conduziram à definição e à redefinição de estratégias de inscrição políticas e culturais mais específicas. O que significa a possibilidade de traçar, na série articulada de configurações de interdependências, o esboço de diferentes fases do mercado de produção de bens simbólicos conjugado ao exame das posições e das tomadas de posição.

\section{NOTÁVEIS LETRADOS E ARQUITETOS DA NAÇÃO (1920-1950)}

No Brasil, o século XX trouxe, como espólio do período imperial, o peso de uma elite restrita, socialmente homogênea e com formação cultural semelhante que se empenhara, notadamente a partir dos anos 1920, na concepção da "identidade nacional". Uma série de reconfigurações mais amplas, como a transferência do eixo dominante das transações culturais da Europa para os EUA, contribuiu para o paulatino deslocamento das posturas intelectuais e políticas, asseveradas na atenuação da ideologia cosmopolita e na ascensão da atitude nacionalista, condicionado por estratégias de reconversão dos herdeiros de famílias dirigentes em declínio econômico (Garcia Jr., 1993; Miceli, 1979).

O desenrolar desse processo foi a urgência de reconstrução do Estado nacional nos anos 1930 e, no seu bojo, o avigoramento do mercado editorial - cujas publicações, não raramente, vinham imbuídas da temática nacionalista -, tributário da diversificação e expansão do mercado de diplomas universitários e fator importante das modificações no espaço de possíveis carreiras intelectuais (Sorá, 2010; Garcia Jr., 1993; Pécaut, 1990; Pontes, 1988; Miceli, 1979). Duas preocupações orientavam singularmente os intelectuais entre 1925 e 1940: a identidade nacional e as instituições. Planando sobre o social, compartilhavam das mesmas representações do fenômeno político de buscar "dentro do 
real, uma unidade anterior a todos os processos de instituição do social e que pudesse escorar as formas de unidade da sociedade política", assim como não dissociavam o exercício de uma atividade intelectual do universo da política (Pécaut, 1990:14-18). A desilusão com a República Velha impulsionou a cooperação dessa geração com o Estado para a "construção da sociedade em bases racionais", apoiados na "marca da origem social", num "elitismo socialmente marcado" e na exibição de títulos que "consistiam na posse de um saber sobre o social, reconhecido e valorizado por amplos setores da sociedade" (idem:22-33).

Afonso de Melo Franco é um personagem por excelência desse período. Nasceu em 1905 na capital de Minas Gerais ${ }^{4}$ e acrescentou o "Arinos" ao nome posteriormente, em homenagem a um tio Afonso Arinos de Melo Franco, escritor regionalista e membro da Academia Brasileira de Letras (ABL). Pertencente a uma tradicional família mineira, contou com a origem social alta em todos os sentidos, constituindo-se como descendente de uma genealogia de políticos, intelectuais, diplomatas e reproduzindo um padrão de transmissão/conquista de posições centrais de poder observado desde o Império ${ }^{5}$.

Os avós, paterno e materno, de Afonso Arinos de Melo foram respectivamente: deputado provincial do Império e senador em Minas Gerais (1892 e 1923); e deputado-geral por Minas Gerais, presidente da província do Rio de Janeiro, governador de Minas (1889-1892), ministro da Justiça (1890), prefeito do então Distrito Federal, Rio de Janeiro (1898-1900). O pai foi deputado estadual por Minas Gerais (1903-1906), deputado federal (1906-1929), ministro da Viação (1918-1919), embaixador do Brasil na Liga das Nações (1924-1926), ministro das Relações Exteriores (1930-1933), presidente da Comissão Constitucional visando a redação do anteprojeto da nova Constituição (1934), constituinte do estado de Minas Gerais (1935) e deputado estadual (até 1937). Virgílio, um dos irmãos mais velhos de Afonso Arinos, foi: líder da juventude civil revolucionária (1930), deputado constituinte por Minas (1934), deputado federal (1935-1937), fundador da União Democrática Nacional (UDN). Outros dois (também mais velhos) seguiram carreiras diplomáticas.

No seu percurso escolar, Afonso Arinos estudou nos Colégios Brasileiro, Anglo-Mineiro e Arnaldo (nos quais foi colega de outras "personalidades" da política e da literatura brasileiras). No Rio de Janeiro, foi frequentando o Internato Pedro II que teria vindo à tona o "seu gosto 
pela literatura escrevendo, entre 1919 e 1920, poesias e artigos para a revista estudantil Primavera" (Abreu et al., 2001:336).

A formação em Direito foi iniciada em 1922 na Faculdade de Direito do Rio de Janeiro (por onde passaram outros contemporâneos ilustres) e, no transcorrer do curso, Arinos acompanhou o pai em missões diplomáticas para Santiago do Chile e Genebra. A obtenção do título de bacharel, no ano de 1927, viabilizou a ocupação do cargo de promotor de Justiça da comarca de Belo Horizonte, exercido à sombra de pressões políticas contra as supostas pretensões do seu pai de concorrer a governador do estado. Nesta estada em Belo Horizonte começou, então, a escrever artigos sobre política internacional no órgão de notícias chefiado por Carlos Drummond de Andrade. Porém, em 1928, desvinculou-se do posto na promotoria, casou-se com a neta de um ex-presidente da República (Rodrigues Alves) e foi residir no Rio de Janeiro (Abreu et al., 2001:337).

Na então capital federal, atuou como fiscal de bancos e advogado de uma grande empresa concessionária dos serviços de distribuição de energia elétrica; vinculou-se a uma rede de intelectuais católicos (Alceu Amoroso Lima, Heráclito da Fontoura Sobral Pinto, Francisco Clementino de San Tiago Dantas e José Lins do Rego) aglutinados em torno da Livraria Católica dirigida por Augusto Frederico Schmidt $t^{6}$; passou a produzir crônicas para O Jornal, de Francisco de Assis Chateaubriand, e para a Revista do Brasil, dirigida por Rodrigo Melo Franco de Andrade (com o qual possuía laço de parentesco). Essas inserções colaboraram para o fortalecimento das relações políticas e literárias de um circuito mineiro de intelectuais com os chamados "modernistas" (Graça Aranha, Sérgio Buarque de Holanda, Prudente de Morais Neto, Ronald de Carvalho, Manuel Bandeira, Gilberto Freyre, Gastal Cruls, Agripino Grieco e Hamilton Nogueira).

Ao mesmo tempo, Afonso Arinos dedicou-se ao empreendimento oposicionista frustrado de composição da chapa encabeçada por Getúlio Vargas e João Pessoa para concorrer nas eleições presidenciais de 1930, pela Aliança Liberal. No entanto, foi internado durante vários meses para tratamento de saúde no Sanatório Hugo Werneck, em Belo Horizonte. Enquanto isso, seu pai (Afrânio de Melo Franco) e seu irmão (Virgílio Alvim de Melo Franco ${ }^{7}$ ) envolviam-se nos arranjos contra o governo federal de Júlio Prestes. Com a instauração do governo provisório de Vargas, o pai fora indicado ao Ministério das Relações Exterio- 
res e ele publicou, pela Graphica Ypiranga, o livro Responsabilidade Criminal de Pessoas Jurídicas. Em meados de 1931, ainda por motivos de saúde, Arinos foi para a Suíça e isso oportunizou sua indicação para ser secretário da delegação brasileira enviada a Genebra para a Conferência Internacional de Desarmamento, ocorrida em 1932.

Com o êxito de Getúlio Vargas em derrotar a Revolução Constitucionalista de São Paulo, as eleições para a Assembleia Nacional Constituinte (incumbida de produzir a nova Constituição e eleger o presidente da República) foram marcadas para maio de 1933. Sem deixar de acompanhar o protagonismo político do irmão (Virgílio), Afonso Arinos assumiu a direção dos jornais Estado de Minas e Diário da Tarde, de Belo Horizonte (ambos faziam parte dos Diários Associados de Chateaubriand e eram politicamente vinculados à facção da qual Virgílio era uma das lideranças); publicou artigos como editor de política e lançou o livro Introdução à Realidade Brasileira pela Coleção Azul da Editora Schmidt no qual teria expressado "aquela fase da revolução brasileira ainda marcada pelo predomínio das elites, da ordem intelectual e das preocupações institucionais" (Arinos, depoimento, apud Abreu et al., 2001:337). Outro ensaio político lançado em 1934 foi "Preparação para o Nacionalismo", este pela Editora Civilização Brasileira. O fluxo de publicações de Afonso Arinos não teve nenhum período longo de estagnação, pelo menos até o início da década de $1980^{8}$.

Depois de ter dirigido o jornal oposicionista Folha de Minas com Virgílio (agora desvinculado do governo central ${ }^{9}$ ), passou a ser assistente de consultoria jurídica do Banco do Brasil no Rio de Janeiro (1935) e assumiu a cadeira de História do Brasil da Universidade do Distrito Federal, fundada por Anísio Teixeira. Inaugurava-se um período de relativa distância das empreitadas políticas (que durou até a metade da década de 1940) e de intensos empreendimentos na condição de "escritor". Neste caso, o espaço para publicações disponível para Arinos merece destaque.

O "florescimento de um mercado do livro" resultou da diversificação e expansão do mercado de diplomas universitários que formou públicos favoráveis (estudantes universitários, professores, funcionários do setor privado, profissionais liberais, entre outros) ao consumo de determinados produtos. Fortaleciam-se os empreendimentos no mercado editorial, a presença de financiadores e a afirmação de produtores e 
produtos de bens culturais variados, notadamente com influência norte-americana (Miceli, 1979).

$\mathrm{O}$ "frenesi de reinterpretar o passado nacional, de interpretar e diagnosticar o presente" consubstanciou-se na produção de coleções publicadas nas maiores editoras do período (Pontes, 1988:58). Se na década de 1920 "editar" era um ofício restrito a alguns imigrantes, nos anos 1930 editoras foram fundadas por brasileiros, sobretudo nos grandes centros urbanos (Rio de Janeiro, São Paulo, Belo Horizonte e Porto Alegre), havendo um aumento de $600 \%$ na edição de livros entre 1930 e 1936, abrangendo livros didáticos (altamente rentáveis), gêneros como a "literatura de ficção em geral e da literatura brasileira em particular" (ibidem:60). Naquela conjuntura, várias coleções foram organizadas para demarcar o debate político e ideológico em jogo (como aquela lançada em 1932, pela Schmidt, a Coleção Azul e, em 1934, pela José Olympio, Problemas Políticos Contemporâneos) e/ou para agregar interpretações sobre a "realidade brasileira" (com destaque para: Brasiliana, Documentos Brasileiros e Biblioteca Histórica Brasileira) ${ }^{10}$.

No decorrer de mais ou menos 12 anos (entre 1935 e 1948), Afonso Arinos foi conferencista em universidades, ministrou cursos no exterior (história econômica e política na Universidade de Montevidéu; cultura brasileira na Sorbonne, em Paris; literatura brasileira na Faculdade de Letras de Buenos Aires; história do Brasil no Instituto Rio Branco) e organizou simpósios que geraram livros. Em 1943 produziu, com outros ativistas (dentre eles, seu irmão), o "Manifesto dos Mineiros", em oposição declarada ao governo varguista. O falecimento do pai nesse mesmo ano estimulou o início da pesquisa e produção do trabalho Um Estadista da República - Afrânio de Melo Franco e seu Tempo ${ }^{11}$, publicado em três volumes 12 anos mais tarde, em 1955, pela livraria José Olympio ${ }^{12}$.

Em 1945 empenhou-se na fundação da UDN, escrevendo o manifesto inaugural com João Mangabeira. Devido à ocupação do cargo de secretário-geral do partido e à desistência em disputar um mandato, Virgílio colaborou na campanha de Arinos à Assembleia Nacional Constituinte, em 1945. E ele, mesmo conquistando somente a primeira suplência da bancada mineira da UDN, com a eleição para governador de Milton Campos, acabou assumindo, em 1947, a vaga aberta na Câmara. Logo foi indicado como vice-líder da bancada udenista e à Co- 
missão de Justiça, tornado-se relator da subcomissão incumbida de formular leis complementares à Constituição (Abreu et al., 2001:338).

Assim, esse personagem adentrou no cenário público num momento em que persistia o "cosmopolitismo introjetado no modo de pensar da elite imperial brasileira" e em que o curso de Direito somente atestava a participação na classe dirigente, com a ocupação de altas posições políticas, administrativas e intelectuais (Alonso, 2002:27; Miceli, 1979:35). Entretanto, essas condições já estavam em reconfiguração. A reforma do ensino superior, que ocorrera no início da década de $1930^{13}$, levou à expansão de outras áreas de conhecimento (Ciências Sociais, Educação, Psicologia, Economia, entre outras), assim como interferiu contundentemente para a diversificação do espaço de concorrência política e intelectual, com a multiplicação dos lugares necessários de inscrição dos agentes visando o acúmulo de trunfos atinentes à conquista ou manutenção de posições (híbridas) bem alocadas, a exemplo da imprensa, das instituições culturais, das organizações políticas etc.

A "expansão da máquina burocrática" no decorrer do regime Vargas e o uso de mecanismos de cooptação empregados pelo Estado agiram na incorporação de agentes com a griffe de "intelectual" no chamado estamento burocrático. Esses, por sua vez, podiam reconverter atributos acumulados nos meios políticos e administrativos para os domínios intelectuais, ocupar lugares em instâncias de consagração "propriamente" culturais (como a ABL) e distinguir-se internamente pela vinculação ou não do trabalho burocrático ao de criação - haja vista que seus bons rendimentos e disponibilidade de tempo poderiam sustentar a dedicação à produção cultural (Miceli, 1979).

No pós-45, especialmente a partir da década de 1950 e até 1965, observa-se um período de intensificação do processo de industrialização, de crescimento econômico e de urbanização do país. Foi criado o Projeto de Lei de Diretrizes e Bases da Educação Nacional, com debates sobre os parâmetros das escolas públicas e privadas e a instituição da Universidade de Brasília (UnB) (1961) - celebrada como o "ápice" da "modernização do ensino superior no Brasil" -, adicionado ao aumento de 161 mil matrículas e à federalização de instituições estaduais e privadas (Martins, 2009; Fávero, 2006).

No plano político, o sistema partidário da denominada "democracia populista" foi em grande parte composto por forças mobilizadas no "regime varguista" ou por setores da "oligarquia" marginalizados no 
mesmo período. As composições sociais dos principais partidos concorrentes, UDN e Partido Social Democrático (PSD), eram diversas em termos econômicos e sociais, sendo a base substancial do recrutamento dos "udenistas" os "círculos de maior prestígio das profissões liberais e intelectuais junto às elites de grandes proprietários rurais em alguns estados nordestinos e nos remanescentes do pessoal político a serviço de antigos clãs oligárquicos já atuantes durante a primeira República" (Miceli, 1981:563), enquanto os "pessedistas" eram majoritariamente selecionados entre lideranças do empresariado industrial, o pessoal político das interventorias e alguns elementos das corporações burocráticas, como as militares. A maior ou menor proximidade com o poder central no Estado Novo constituía a força de atração para uma ou para a outra sigla.

Afonso Arinos movimentou-se, no espectro de forças partidárias, em oposição aos partidos considerados pró-Vargas (PSD e PTB - Partido Trabalhista Brasileiro), por terem sido mobilizados pelo comando do Estado Novo. Liderou, pois, a sigla (UDN), que reunia dirigentes políticos estaduais anti-Vargas. Ao longo da sua carreira política, compôs a Comissão de Reforma Administrativa, foi relator da Comissão Especial para emitir parecer sobre a autonomia do Distrito Federal e propôs a lei contra a discriminação racial. Com as teses intituladas As Leis Complementares da Consituição e História e Teoria do Partido Político no Direito Constitucional Brasileiro, conquistou as cátedras de direito constitucional nas Universidades do Distrito Federal (atual Universidade do Estado do Rio de Janeiro - UERJ) e do Brasil (atual Universidade Federal do Rio de Janeiro - UFRJ), entre 1949 e 1950, quando ocupava o primeiro de três mandatos como deputado federal. Reeleito em 1950, assumiu novamente seu mandato em 1951, ano da aprovação da lei contra o preconceito de raça e de cor que ganhou o seu nome (Lei no 1.390, de 3 de julho de 1951).

Foi em 1951 também que Getúlio Vargas assinou a Lei no 1.411 que instituiu a profissão de economista no Brasil, coincidindo com o ano em que Antônio Delfim Netto diplomou-se em Economia na Faculdade de Ciências Econômicas e Administrativas da Universidade de São Paulo (FEA-USP) $^{14}$, instituição na qual ingressara em 1948 (terceira turma) após ter obtido, em 1946, o título de Contador pela Escola Técnica de Comércio Carlos de Carvalho (Macedo, 2001:375).

Filho de uma costureira e de um funcionário da empresa de transportes da Prefeitura de São Paulo, Delfim começou a trabalhar como contí- 
nuo ou office boy depois do falecimento do pai, aos 14 anos de idade (quando ele nasceu, Arinos era promotor de Justiça em Belo Horizonte), e com 18 anos, frequentou a Escola Técnica. No período em que ainda realizava o curso universitário, trabalhou no Departamento de Estradas e Rodagem, ocupação que lhe permitiu escrever textos como “Uma Estimativa de Custos de Operação dos Equipamentos Rodoviários" e "Alguns Métodos Estatísticos para Cálculos de Depreciação numa Economia Sujeita à Inflação". Suas origens sociais são, portanto, semelhantes àquelas de seus contemporâneos de Faculdade de Economia da USP, instituição que, como mostrou Loureiro, era "procurada por jovens de extração social mais baixa, provenientes de escolas técnicas do comércio que não tinham condições econômicas de frequentar escolas de Direito ou Engenharia" (1992:57).

Depois de formado, Delfim Netto conseguiu uma posição como assistente do professor Luiz de Freitas Bueno ${ }^{15}$ (catedrático de econometria) na cadeira de Estatística I e, em 1953, atuou na Bolsa de Mercadorias de São Paulo como professor de um curso de análise matemática para economistas (Abreu et al., 2001:1806).

Também foi em 1953 que, à frente da bancada udenista, Arinos se opôs frontalmente ao governo de Getúlio Vargas, chegando a advogar pelo cumprimento do tratado militar entre o governo brasileiro e o norteamericano em função da "Guerra Fria" e do "princípio da solidariedade continental". Confirmado pelo Congresso em março do mesmo ano (com vigor até 1977), o acordo era apontado como possibilidade de "modernização dos equipamentos militares" e como assistência técnica dos EUA, tendo sido criticado, sobretudo, pelo provável interesse do governo daquele país "na requisição de tropas brasileiras para a guerra na Coréia" (Abreu et al., 2001:339).

Persistindo na oposição ao governo, Arinos contestou a política de cooperação entre as diferentes agremiações partidárias empreendida por Vargas e, em 1954, suas críticas foram intensificadas e vertidas com o manifesto de 82 coronéis e tenentes-coronéis contra o aumento de $100 \%$ do salário mínimo apresentado pelo então ministro do Trabalho, João Goulart, o que interferiu na substituição deste último por Hugo Faria, assim como na modificação do ministro da Guerra. Com o atentado contra Carlos Lacerda (UDN) e a morte do major-aviador Rubens Vaz, em agosto do mesmo ano, os conflitos entre governo e oposição se 
exacerbaram e Arinos discursou pelo afastamento do presidente (idem).

O suicídio de Vargas ocorreu justamente em 1954 causando imensa comoção popular, favorecendo o relativo aumento do apelo eleitoral do PSD e do PTB, enquanto a UDN sofreu o prejuízo de 10 cadeiras na Câmara Federal. Mesmo assim, Afonso Arinos conseguiu reeleger-se pela terceira vez com uma votação quatro vezes maior do que aquela obtida na estreia.

A despeito da intensa campanha de oposição das lideranças udenistas e das autoridades militares, a chapa Juscelino Kubitschek (presidente) e João Goulart (vice) venceu as eleições de outubro de 1955, constituindo-se imediatamente em alvo de condenações dos partidários da UDN, que pretendiam impedir judicialmente a posse dos eleitos. A favor de uma saída legal, Arinos defendeu, sem sucesso, a reapresentação da emenda parlamentarista de Raul Pilla ${ }^{16}$. Depois concentrou suas censuras na corrupção, no crescimento da taxa de inflação e no aumento dos gastos públicos, especialmente o "desperdício" representado pela construção de Brasília ${ }^{17}$. Em 1957, ocupou a posição de líder do Bloco Parlamentar de Oposição (UDN, PL - Partido Liberal e PDC Partido Democrata Cristão), ao mesmo tempo que o deputado Carlos Lacerda passava a liderar a bancada da UDN na Câmara ${ }^{18}$.

Em 1958, Afonso Arinos chegou ao Senado pelo Distrito Federal (atual estado do Rio de Janeiro), derrotando um dos filhos de Getúlio Vargas, vitória que coroou o protagonismo político alcançado no plano nacional e indicava ainda o incremento da força política de Carlos Lacerda, da UDN e dos discursos oposicionistas na capital do país. Presidente da Comissão de Relações Exteriores, apoiou a campanha de Jânio Quadros que, eleito, retribuiu com a sua nomeação para o Ministério das Relações Exteriores em 1961. Todavia, foi substituído sob a chefia de Tancredo Neves (primeiro-ministro durante a experiência parlamentarista instaurada em virtude da renúncia de Jânio Quadros e a disputa travada em torno da posse do seu vice, João Goulart, tido como o "herdeiro de Getúlio Vargas") e seguiu atuando no âmbito das relações internacionais. Porém, com a posse de Francisco de Paula Brochado da Rocha (outro primeiro-ministro empossado no início da década de 1960), voltou a assumir a chefia do Itamaraty. Neste período: chefiou a XVI Assembleia Geral da ONU; comandou a delegação brasileira que participou da Conferência do Desarmamento em Genebra; 
compareceu ao Concílio Vaticano II na condição de Embaixador extraordinário; e esteve à frente da delegação brasileira na XVII Assembleia Geral da ONU (Abreu et al., 2001:340).

Antes da eleição ao Senado, em janeiro de 1958, Afonso Arinos teve êxito no pleito à Academia Brasileira de Letras (venceu João Guimarães Rosa), ocupando a vaga de José Lins do Rego. Foi saudado por Manuel Bandeira em sua investidura, ocorrida em julho do mesmo ano.

Nota-se que, nesse momento, quando o debate intelectual foi dominado por outras versões de nacionalismos (diferentes daquela prevalecente nos anos 1930), a produção de Afonso Arinos voltou-se para a consagração pessoal e familiar. Do mesmo modo, centrou-se em temas ligados às liberdades democráticas e ao estado democrático de direito, condizentes com as suas adesões políticas conjunturais, assim como com os atributos que então acionava. Posicionou-se sobre questões nacionalistas no Senado, no Ministério das Relações Exteriores e no desempenho das atribuições diplomáticas assumidas no período. Foram tratadas as temáticas do desenvolvimento, da afirmação nacional, da autodeterminação e da soberania, associadas a discussões sobre relações internacionais ${ }^{19}$.

Os tipos de publicação privilegiados por Arinos, por sua vez, voltavam-se à produção de memórias, biografias históricas, poesias e temas especializados do direito que possuem interface com a organização do sistema político ${ }^{20}$. Logo, manteve-se relativamente distante das disputas entre intelectuais ligados às Ciências Sociais, posicionados mais à esquerda, que disputavam a bandeira da soberania nacional (Pécaut, 1990:99), e daquelas que dominavam o espaço dos economistas (monetaristas $x$ estruturalistas), que debatiam questões relativas ao nacionalismo, ao desenvolvimento industrial, ao planejamento econômico, à reforma agrária etc. (Loureiro, 1992:63).

\section{A NOVA LINGUAGEM DO PODER: ECONOMISTAS NOTÁVEIS ${ }^{21}$ E A FORÇA DA BUROCRACIA}

Há uma forte associação entre a posse de título escolar em economia e a dedicação ao gênero setorialista (Grill e Reis, 2012). Isto é, 86\% dos agentes com formação superior em economia escreveram precipuamente livros dedicados à sua área de formação, mobilizando seus conhecimentos escolares e "competências" técnicas. Quase 70\% desses casos analisados possuem pós-graduação na área, mais da metade de- 
les com experiência de internacionalização nas suas apostas acadêmicas em nível de mestrado e doutorado. Desses, praticamente todos atuaram no magistério superior ministrando cursos ligados à disciplina de economia. Outro dado vultoso obtido naquele levantamento foi a existência de dois padrões de carreiras políticas entre os parlamentares com formação em economia. De um lado, aqueles que exerceram cargos na esfera administrativa a partir do reconhecimento que adquiriram como profissionais e docentes da área de economia (em torno de $55 \%$ dos casos). De outro, agentes que se dedicaram primordialmente a carreiras eletivas, não demonstrando conjuntamente uma especialização em assuntos econômicos no desempenho das suas funções públicas (próximo a $45 \%$ dos casos).

Nessa população especificamente composta por economistas com extensa produção bibliográfica e com passagem pelo Parlamento brasileiro, o ex-ministro Delfim Netto é um representante exemplar. Portador de um currículo acadêmico marcado pela nova linguagem matematizada e dolarizada da economia ${ }^{22}$ e pelo pertencimento a centros de pesquisa considerados de excelência, ocupou cargos administrativos de relevo no aparato burocrático nacional durante o regime militar (1964-1985) e postos políticos (parlamentares e partidários) de destaque nas últimas décadas. Por meio do seu itinerário de mais de quatro décadas de atuação na cena pública percebe-se transformações mais gerais em espaços de concorrência das lideranças, equilíbrios e tensões na balança de poder, entradas de novos protagonistas e linguagens, saídas, reconversões e adaptações de agentes relativamente estabelecidos no jogo político.

No mesmo ano em que Arinos entrou para a ABL (1958), Delfim Netto foi aprovado no concurso para livre-docente de estatística econômica, com a tese intitulada O Problema do Café no Brasil, e conquistou a condição de professor catedrático de economia brasileira na Faculdade de Ciências Econômicas e Administrativas da USP. Seu trabalho foi publicado pela própria FEA-USP em $1959^{23}$, ano em que foi eleito vice-presidente da Ordem dos Economistas de São Paulo. Além disso, passou a compor o conselho editorial da Revista de Ciências Econômicas; foi assessor econômico na Associação Comercial de São Paulo (pela qual publicou, em coautoria com Luiz Mendonça de Freitas, o livro $O$ Trigo no Brasil, em 1960); e recebeu o convite para fazer parte da equipe de planejamento do governo paulista. 
Subsequentemente, desempenhou funções na Comissão Interestadual da Bacia Paraná-Uruguai, no Serviço Estadual de Mão de Obra da Secretaria do Trabalho do governo estadual, no Conselho Técnico Consultivo da Assembleia Legislativa, e produziu pesquisas para a Associação Nacional de Programação Econômica e Social, entidade financiada por banqueiros paulistas, e publicou, em 1964, o texto "Alguns Aspectos na Inflação Brasileira".

No âmbito acadêmico, Delfim foi diretor de pesquisa da FEA-USP ${ }^{24}$ e, por esta mesma Instituição, em 1963, prestou concurso e obteve o título de professor catedrático de teoria do desenvolvimento econômico com o estudo "Alguns Problemas do Planejamento para o Desenvolvimento Econômico". Despontava como "o primeiro economista formado depois da regulamentação da profissão a ocupar uma posição de Catedrático nessa faculdade" 25 .

Com sua significativa intervenção, membros da FEA, em 1964, criaram o Instituto de Pesquisas Econômicas (IPE) como centro complementar do Departamento de Economia e com o fim de realizar pesquisas econômicas e financeiras. O Instituto teve forte atração entre os poderes públicos e o empresariado, e resultou na Fundação Instituto de Pesquisas Econômicas (Fipe) na década de 1970. Tais empreendimentos contaram com a contribuição do programa da United States Agency for International Development (USAID), que fomentava a vinda de professores norte-americanos para esse tipo de instituição de pesquisa, bem como propiciava a ida de pesquisadores brasileiros para os EUA. O acordo MEC/USAID teria sido o responsável "pela formação de nova geração de professores do Departamento de Economia ao longo da década de 1970, os quais, nos anos seguintes, chegaram aos cargos de professor-titular, com a aposentadoria dos antigos catedráticos" (Macedo, 2001:383).

Três medidas tomadas pelo governo em relação às universidades são paradigmáticas. A primeira foi o acordo citado acima, que oficializou a "assistência" técnica, financeira e militar dos EUA ao Brasil. A segunda diz respeito à consultoria dada ao MEC, em 1965, pelo norte-americano, membro da USAID, Rudolph Atcon. O relatório de Atcon serviu de base para a produção do documento "Rumo à Reformulação Estrutural da Universidade Brasileira", cuja proposição às universidades brasileiras enfatizava a "defesa dos princípios de autonomia e autoridade, dimensão técnica e administrativa do processo de reestrutura- 
ção do ensino superior, ênfase nos princípios de reformulação do regime de trabalho docente, criação do centro de estudos básicos... [e] de um conselho de reitores", o CRUB (Conselho de Reitores das Universidades Brasileiras), do qual Atcon foi o secretário-geral de 1966 a 1968 (Fávero, 2006:15). Com a presidência do general Meira Mattos, a terceira medida foi a constituição de uma comissão especial incumbida de agir no sentido de reprimir/dirimir as mobilizações a partir do âmbito universitário (idem; Martins, 2009).

A década de 1970, junto com a reforma universitária que extinguiu as cátedras, parece ter sido o ápice da escalada da versão da "dolarização do conhecimento", particularmente no tocante ao ensino de economia quantitativa, de aplicação prática, a qual Delfim filiou-se.

No plano político, por sua vez, é patente a progressiva importância de instâncias burocráticas no processo decisório e, por conseguinte, a relevância dos burocratas como atores centrais das decisões governamentais (em detrimento dos "políticos"). Não por acaso, a bibliografia temática ressalta a atuação dessa burocracia estatal na condução de políticas econômicas e na montagem do estado nacional-desenvolvimentista. Isto é, sublinham como determinadas agências de Estado passaram a monopolizar as atribuições de regulação, financiamento e planejamento econômico ${ }^{26}$.

Dois aspectos, no entanto, devem ser ponderados. Primeiro, a demonstração da força do papel dos "técnicos" nesta seara e no interior do chamado aparelho de Estado não significa, conclusivamente, que o lugar desfrutado por esses agentes seria definido exclusivamente em função da sua competência técnica ou do saber especializado proclamados, assim como não se pode assegurar que os mesmos estivessem imunes à dependência de outros recursos de afirmação, como o estabelecimento de alianças estratégicas com protagonistas da política eletiva. Ademais, e em segundo lugar, os ocupantes desse espaço burocrático muitas vezes são eles próprios os atores das disputas partidárias. Afora o fato de que os conhecimentos (fundamentalmente escolares), mobilizados para as tarefas de planejamento e regulação econômica nem sempre foram monopólio de economistas, tampouco os postos nos organismos governamentais que regem a economia são "por natureza" ou automaticamente ocupados por indivíduos com formação econômica. 
Loureiro mostra as especificidades do caso brasileiro examinando as condições histórico-estruturais, bem como o trabalho coletivo de instituições e grupos diversificados que ensejaram a afirmação acadêmica e governamental da ciência econômica no país, quer dizer, do seu lugar de destaque no âmbito das instituições de ensino superior e das agências governamentais. A "nova competência política", simbolizada por uma "qualificação técnico-profissional" e associada a modelos matemáticos sofisticados, quantificação, predição etc. resultou das características sociais dos seus "promotores" (muitos deles, aliás, além de já estabelecidos social e politicamente, acumularam também outros títulos, como em Direito). Do mesmo modo derivou da "montagem institucional que certos grupos puderam empreender, tanto no âmbito do aparelho do Estado quanto nos meios intelectuais e universitários" (Loureiro, 1992:49).

Foi entre 1964 ou 1965 que Delfim Netto inaugurou sua inscrição federal compondo o Conselho Consultivo de Planejamento (Consplan) e, por indicação de Roberto Campos (então ministro do Planejamento), integrou o Conselho Nacional de Economia. Este mesmo ministro o indicou para o cargo de secretário da Fazenda do Estado de São Paulo. Nesta pasta ficou até 1967, quando assumiu a função de ministro da Fazenda ${ }^{27}$. Durante a década de 1960, Delfim Netto publicou um conjunto de livros sobre a questão econômica, em especial sobre aspectos da agricultura e do café no Brasil ${ }^{28}$.

Na gestão do Ministério da Fazenda, com o Plano Estratégico de Desenvolvimento (PED), Delfim protagonizou um momento de ascensão da economia nacional, com uma baixa de $23 \%$ da inflação e um crescimento de $4,8 \%$ do Produto Interno Bruto (PIB), tendo no desempenho da indústria, principalmente no setor de bens duráveis de consumo, o carro-chefe desse crescimento. Do ponto de vista econômico, alguns fatores conjunturais teriam contribuído para essa reativação do crescimento:

(...) a grande expansão do comércio e da liquidez internacionais no período, a expansão do setor público, responsável pela absorção de grande parte da capacidade ociosa do parque industrial brasileiro, a consolidação do mercado de capitais e do sistema financeiro nacionais e a política de achatamento salarial (Abreu et al., 2001:1807).

Entretanto, o período foi de fortalecimento das mobilizações conduzidas pelos antagonistas do governo estabelecido. Notadamente, lide- 
ranças políticas, intelectuais, setores da Igreja Católica e estudantes promoveram formas diversas de articulação e de contestação ao regime (composição de organizações clandestinas, reuniões, encontros, manifestações, produção de documentos, grupos de estudo, propagandas impressas, projetos de guerrilha etc.) que geraram confrontos com a polícia. Para a contenção das mobilizações, os setores militares mais radicais conseguiram fazer instituir, em dezembro de 1968, o Ato Institucional oㅗ 5, assinado pelo presidente da República e seus ministros (incluindo Delfim).

No momento do golpe militar, em Minas Gerais, Afonso Arinos era secretário do governo e fora eleito presidente da Comissão de Constituição e Justiça do Senado, até Roberto Campos assumir este posto em 1965. Neste mesmo ano, publicou o segundo volume das suas memórias, intitulado Escalada (José Olympio), e o livro Evolução da Crise Brasileira (pela Companhia Editora Nacional). Em 1966, divulgou cinco discursos sobre a reforma constitucional, participou da criação da Aliança Renovadora Nacional (Arena), produziu uma versão para o capítulo do anteprojeto de Constituição referente aos direitos e garantias individuais (por solicitação do líder da maioria no Senado, Daniel Krieger) e apresentou uma emenda indicando a instituição do regime parlamentarista.

Terminado o mandato de senador, sem concorrer à reeleição, Arinos foi nomeado membro do Conselho Federal de Cultura (CFC). Tornou-se, assim, um dos "cardeais da cultura nacional" 29 junto com outros intelectuais que, à frente do CFC, encabeçaram a política para o setor cultural em um momento (1967-1978) em que o Estado atuou como "agente financiador e organizador de projetos culturais, tornando-o o grande mecenas da cultura brasileira" (Maia, 2012:25-26). Como outrora, os membros do conselho teriam se centrado em forjar concepções acerca da "cultura nacional", desta vez alicerçando-se num sentido de "civismo", isto é, defendendo "a formação de uma 'consciência cívica'" como sendo "necessária à convivência harmônica entre o estado e a sociedade civil" (ibidem:28) .

Além de Afonso Arinos, participavam do CFC: Gilberto Freyre, Pedro Calmon, Josué Montello, Gustavo Corção, Djacir Lima Menezes, João Guimarães Rosa, Rachel de Queiroz, Ariano Suassuna, Roberto Burle Marx, Hélio Viana, entre outros que, segundo Tatyana Maia, "eram companheiros de uma longa trajetória no campo político e intelectual iniciada naqueles estonteantes anos 1920". Cabendo sublinhar aqui 
que a "identidade de grupo" fundava-se em "laços de companheirismo e amizades", bem como "era associada aos cargos exercidos nas fileiras do Estado" (Maia, 2012:42-43).

Afonso Arinos, entre 1967 e 1969, investiu na publicação do segundo volume de História do Povo Brasileiro (1967, Editores Culturais); na ABL proferiu o discurso de recepção a João Guimarães Rosa; lançou a segunda edição de "Curso de Direito Constitucional Brasileiro" (Revista Forense), além do terceiro volume de suas memórias Planalto (1968, José Olympio) e História do Povo Brasileiro, em colaboração com Jânio Quadros (1968, Editores Culturais). No início da década de 1970, publicou uma brochura do curso de extensão ministrado na Pontifícia Universidade Católica do Rio Grande do Sul sobre "História das Idéias Políticas" (1970); ganhou o prêmio Intelectual do Ano conferido pela Sociedade Paulista de Escritores (1973); lançou a segunda edição da História do Banco do Brasil e Rodrigues Alves - Apogeu e Declínio do Presidencialismo (1973, José Olympio) e Jean Baptiste Debret (1974, Editora Fontana). Em 1975, Arinos se aposentou do magistério, criou a Fundação Milton Campos (Centro de Estudos Políticos ligado à Arena) e divulgou "Problemas Políticos Brasileiros" e a segunda edição de Pela Liberdade de Imprensa (José Olympio). Em 1976, publicou a segunda edição de $O$ Índio Brasileiro e a Revolução Francesa (José Olympio), e de Um Estadista da República (Nova Aguilar), o quarto volume das suas memórias Alto-mar-Maralto (José Olympio) e Direito Constitucional (1 1 edição, Forense). Em 1979, o quinto volume de suas memórias Diário de Bolso seguido de Retrato de Noiva (Editora Nova Fronteira).

Ocorria então o início da "distensão lenta, gradual e segura" quando Delfim Netto ocupou o posto de Embaixador do Brasil na França, permanecendo em Paris de 1975 a 1978 (a equipe ministerial foi redefinida com a posse de Ernesto Geisel, em 1974). Em 1979, após deixar o cargo, viu frustrada a sua pretensão de ser o governador de São Paulo pela Arena (partido de sustentação do regime militar) e foi acusado de subestimação dos índices inflacionários de 1973. Porém, teve êxito na indicação para ocupar o Ministério da Agricultura no governo do general João Baptista Figueiredo - foi formado um "ministério de composição entre o chamado 'grupo da Sorbonne', ligado às origens da Escola Superior de Guerra, e a equipe mais próxima ao ex-presidente Geisel" (Abreu et al., 2001:1809).

A crise internacional e os descontentamentos relativos à combinação de ineficácia das medidas contencionistas adotadas e o crescimento da 
inflação ("em virtude do aumento dos custos financeiros das empresas e do agravamento do déficit do Tesouro"), levaram à renúncia do então secretário de Planejamento, Mario Henrique Simonsen, e à nomeação de Delfim na chefia da Seplan, em 15 de agosto de 1979, na qual ficou até 1985. Neste período, publicou a segunda edição de O Problema do Café no Brasil (1981, pela Fipe/USP); assumiu a cátedra de análise macroeconômica na USP (1983); negociou novo empréstimo junto ao Fundo Monetário Internacional (1983); defendeu uma política salarial (orientada pelo FMI) que limitava o reajuste dos salários a 80\% do Índice Nacional de Preços ao Consumidor (INPC) (1983); escreveu "Mudanças Estruturais da Economia no Governo Figueiredo" (1984, pela Seplan); foi denunciado pelo envolvimento no caso Coroa-Brastel ${ }^{31}$ (idem).

Delfim Netto coordenou ainda a campanha exitosa do ex-presidente Jânio Quadros (coligação PTB-PFL - Partido da Frente Liberal) à Prefeitura de São Paulo (derrotando o peemedebista Fernando Henrique Cardoso), em 1985. Desde essa atuação, apostou sistematicamente na arena político-eleitoral incrementada, principalmente, a partir da Assembleia Nacional Constituinte, eleita em 1986.

Enquanto isso, Afonso Arinos seguia empenhado no trabalho de sustentação intelectual de seus posicionamentos políticos e jurídicos. Chegou a fazer uma "pesquisa de opinião", enviando questionários para prefeitos, professores de direito, juristas, dirigentes sindicais, empresários, políticos e profissionais liberais, visando perscrutar "as aspirações médias da sociedade" que poderiam servir de "subsídios para uma reforma da Constituição brasileira" (Abreu et al., 2001:342). Isso no mesmo ano (1980) em que substituiu Temístocles Cavalcanti, falecido, na diretoria do Instituto de Direito Público e Ciência Política (Indipo) da Fundação Getulio Vargas (FGV), "voltado para a pesquisa e comandado por juristas líderes do pensamento brasileiro" (Rodrigues e Falcão, 2005:6-7). Os resultados da pesquisa foram publicados na Revista de Ciência Política (Indipo, 1984).

Com a vitória de Tancredo Neves no Colégio Eleitoral de janeiro de 1985, Arinos foi indicado para presidir essa Comissão Provisória de Estudos Constitucionais, responsável por apresentar propostas à Constituinte, mantida mesmo com a posse do vice-presidente José Sarney na chefia do Executivo, após a morte de Tancredo. Ficou conhecida como "comissão Afonso Arinos" e rotulada, por seus oponentes, 
como uma "comissão de notáveis". Formada por 50 personalidades de juristas, advogados, professores de direito, empresários, cientistas sociais, jornalistas, um médico e um economista, a composição foi contestada por lideranças da Ordem dos Advogados do Brasil (OAB), Central Única dos Trabalhadores (CUT) e Conferência Nacional dos Bispos do Brasil (CNBB), enfim, lideranças que a identificavam como tendo "um caráter conservador e elitista" (Abreu et al., 2001:342).

Na ocasião de entrega do texto ao presidente, Arinos foi condecorado com a Grã-Cruz da Ordem Nacional do Mérito. Em novembro do mesmo ano, candidatou-se ao Senado, sendo eleito constituinte pelo PFL em aliança com o Partido do Movimento Democrático Brasileiro (PMDB). Faleceu antes de concluir o último mandato de senador. Seu livro Presidencialismo ou Parlamentarismo, em colaboração com Raul Pilla, foi reeditado em 1999, pela Editora do Senado.

Nota-se como, na fase final de sua carreira, Afonso Arinos agregou às certificações conquistadas via títulos em direito, exercício do magistério superior, produção de livros e artigos, outros domínios em técnicas e saberes como a produção de pesquisas de opinião, a atuação em fundações de estudos em partidos e em conselhos na esfera pública. Ajustava-se, portanto, à linguagem do poder progressiva e crescentemente importada das instituições norte-americanas e fundada na credibilidade científica e na adesão à ideologia democrática.

Nas últimas décadas, Delfim Netto, por sua vez, publicou vários trabalhos, ocupou postos e acumulou honrarias de diversas ordens. Foi presidente da Comissão de Finanças e Tributação da Câmara dos Deputados; vice-presidente e presidente do diretório nacional do Partido Democrático Social (PDS); eleito Economista do Ano pela Ordem dos Economistas de São Paulo; vice-presidente do Partido Progressista Brasileiro (PPB); membro-titular da comissão especial do projeto sobre o Sistema Financeiro Nacional; entre outras.

Em 1987, Delfim Netto escreveu o texto "Só o Político Pode Salvar o Economista" e, principalmente na segunda metade da década de 1990, produziu uma multiplicidade de artigos para revistas mais ou menos especializadas de grande circulação, como Economia Aplicada, Exame, Conjuntura Econômica, Carta Capital, Isto É Dinheiro, entre muitas outras, principalmente para a FEA-USP. Dentre os livros, destacam-se as coautorias de O Plano Real e a Armadilha do Crescimento Econômico (Unicamp/IE, 1997), 50 Anos de Ciência Econômica no Brasil (Vozes, 1997) e 
O Futuro da Indústria no Brasil e no Mundo: Os Desafios do Século XXI (Campus, 1999), e ainda a publicação de A Crônica do Debate Interditado (Topbooks, 1998) e Como as Nações se Desenvolvem (Campus, 1999).

Como é possível observar, ao longo do seu itinerário, Delfim ocupou quase sempre cargos administrativos, de consultorias e assessorias fundadas na sua formação em economia, assim como os seus textos dificilmente fogem dessa área, seja ela numa perspectiva mais especializada ou generalista ${ }^{32}$. Posteriormente, consagrado por sua escalada de office boy a "czar da política econômica", passando por posições de poder e de produção científica (Macedo, 2001), Delfim Netto ocupou o cargo de deputado federal de 1987 a 2006.

Os percursos de economistas-parlamentares revelam distintas vias de notabilização que guardam relação com a posse do título de economista. Quer dizer, mesmo no período democrático inaugurado nos anos 1980, o monopólio das decisões na área econômica permaneceu sob o controle de grupos de economistas que gozavam de notoriedade nos meios universitários, fator que a manteve como o meio de expressão e legitimação anteposta no espaço político. Assim, o avigoramento desse instrumento como recurso indispensável à produção de explicações não apenas ao mundo econômico, mas também sobre políticas sociais, culturais e arranjos democráticos, impulsionou os investimentos de pretendentes à ocupação das posições de poder nesse tipo de saber (Loureiro, 1997).

Acentua-se no período recente, da mesma maneira, a progressiva valorização de recursos adquiridos nas instituições de ensino em grandes centros (no Chile, na Europa e, principalmente, nos Estados Unidos) e a autoridade (ou suposta "neutralidade") fundada na posse de uma competência "científica" e acadêmica - tanto mais eficaz quanto mais alicerçada no acúmulo e ativação do "capital internacional". A consolidação de princípios de expertise e o consenso acerca da preeminência democrática teriam sido determinantes para a substituição dos políticos-bacharéis pelos técnicos-políticos logo, para a reconfiguração dos espaços de luta pelo poder em suas diferentes dimensões e direções (Dezalay e Garth, 2000; Guilhot, 2001).

Sendo assim, processos deste tipo estão na gênese da redefinição de competências e códigos de realização política, o que significa a emergência e ascensão de novas categorias de profissionais no espaço político ou usos diversificados dos mesmos títulos ao sabor dos 
alinhamentos partidários e ideológicos em curso. A configuração internacional esboçada e as lógicas exógenas que progressivamente se impõem nos países do sul, interagem com as modificações endógenas da agenda de problemáticas, causas e etiquetas legítimas próprias às realidades nacionais não centrais. Os jogos de poder fundem lógicas governamentais e não governamentais, ou estatais e não estatais, desenhando arenas coabitadas por profissionais que transitam em empresas de consultoria, organizações não governamentais, movimentos sociais, centros universitários de pesquisa, associações categoriais, cargos políticos (eletivos ou administrativos) numa conexão simbiótica entre militância e expertise (Guilhot, 2001; Buclet, 2009; Reis, 2013) $)^{33}$.

\section{CONSIDERAÇÕES FINAIS}

As modificações conjunturais e estruturais ocorridas ao longo do século XX são, no mesmo golpe, produto e produtoras da reordenação de diversos segmentos de "elites" e da recomposição dos grupos dirigentes, operando amplas transformações nas linguagens, hierarquias e repertórios de atuação nos espaços do poder nacionais e transnacionais.

Grifam-se os condicionantes e os efeitos (em diferentes níveis e configurações nacionais) da ingerência norte-americana e do deslocamento do eixo das transferências culturais outrora marcados pela ascendência europeia. Uma das consequências foi a afirmação dos "técnicospolíticos" (com fortes influências "dolarizadas" e uma linguagem econômica do poder) em detrimento dos "políticos-bacharéis" oriundos de famílias "tradicionais" (com influências "cosmopolitas" e uma linguagem honorífica do poder $)^{34}$.

Enlaçado a isso, ocorreram processos de recomposição daquilo que define uma condição de intelectual e das imbricações necessárias para armazenar notabilidades múltiplas, condizentes com a capacidade de trânsito entre e em espaços nacionais e transnacionais, com uma profusão de certificações advindas do pertencimento a lugares que aferem excelência social (de acessos raros, extraordinários) e com conexões possíveis a causas vistas como desinteressadas ("nobres", "universais", "transcendentais", até mesmo "sagradas").

Em que pese a exigência crescente de determinados tipos e usos de saberes e qualificações, é possível identificar a personificação desses atributos em personagens híbridos, uma vez que são hábeis em: acu- 
mular sinais de distinção devido à proximidade com a esfera científica que demonstram; entabular teias de relações no domínio político que garantem acessos, aliados, meios de luta e superfície de influência; monopolizar a mediação de "grupos", "segmentos", "interesses" específicos que eles mesmos auxiliaram a edificar. Quer dizer, trata-se de agentes que se notabilizam na ocupação de posições de porta-vozes de temas legítimos por meio da inscrição simultânea ou sucessiva em várias dessas instâncias.

Os dois casos aqui analisados, Afonso Arinos e Delfim Netto, retratam as faces dos criadores e das criaturas desses processos. O primeiro é contemporâneo da geração que se dedicou a pensar os "rumos da nação", letrados pertencentes a famílias estabelecidas, próximos dos núcleos centrais do espaço do poder, dotados de competências políticas (herdadas e adquiridas) e envolvidos em projetos de instituições de formação de quadros dirigentes. O segundo é um exemplar de rotas ascendentes e alicerçado no pertencimento a um segmento específico das elites dirigentes no Brasil, aquele associado à competência técnicocientífica, condição essa reforçada pelo lugar ocupado no regime autoritário que proporcionou o acesso aos organismos governamentais e vantagens em relação aos seus concorrentes externos (políticos tradicionais ou homens de partido).

Enfim, tratou-se aqui de agentes que se distinguem em termos geracionais, não somente devido às datas de nascimento, mas também por suas entradas na política, eventos marcantes e seus interlocutores/concorrentes na arena pública. Nas dinâmicas e estratégias de afirmação, acionaram, de modo contrastante, os saberes detidos com vistas à intervenção nas agendas de "problemas sociais" que os interpelaram, sobretudo no que diz respeito ao uso dos títulos escolares e aprendizados em geral explicitados na ênfase de registros mais generalistas ou mais técnicos na produção de suas tomadas de posição (indissociavelmente políticas e intelectuais). Conjuga-se a isso as divergentes identificações político-ideológicas relativas ao espectro de forças políticas dominantes em momentos conjunturais contínuos.

Entretanto, de um modo geral, as trajetórias demonstram em comum a forte multiposicionalidade que garante as multinotabilidades acumuladas. Aproximam-se igualmente no fato de que, mesmo em diferentes momentos, posicionaram-se na linha de frente das batalhas em torno de concepções ou modelos de "Estado" e "sociedade", de "cultura" e 
"economia", que geraram polêmicas (defesa do parlamentarismo, do mercado econômico etc.), bem como refletiram e contribuíram para a adoção de parâmetros de conduta e de pensamento ainda em voga. Assim, constituíram-se como intérpretes da "realidade nacional" (prescrevendo o que seriam os "melhores" caminhos possíveis ou necessários para o Brasil) e se pretenderam seus operadores, apresentando-se como aptos a ocupar a posição de condutores a partir do exercício de cargos políticos.

(Recebido para publicação em outubro de 2013)

(Reapresentado em outubro de 2014)

(Aprovado para publicação em dezembro de 2014) 


\section{NOTAS}

1. Ver Santos e Pegurier (2011); Marenco (2001); Meneguello (1998), entre outros.

2. Ver Costa e Codato (2013); Coradini (2007 e 2011); Perissinotto e Miríade (2009); Reis (2008); Marenco e Serna (2007); Rodrigues (2002). Para um balanço acerca de estudos de carreiras políticas na pista seguida neste artigo, ver Grill (2013).

3. Esta discussão está presente na apresentação do dossiê publicado na revista Politix (2004), dedicado justamente a pesquisas que tomam como base de análise diferentes configurações de notabilidades. As diferentes pesquisas que se apropriaram dessa concepção revelam um mosaico de qualidades sociais que são atribuídas aos notáveis em diferentes contextos e como são reconvertidas em capital político.

4. Minas Gerais ocupa o segundo lugar (12,1\%) entre os estados mais frequentes de proveniência dos agentes computados no banco mais amplo dos 1.181 casos, antecedido por São Paulo, que ocupa o primeiro lugar (15,7\%) e é o estado de origem de Delfim Netto. Grifa-se que essas posições permaneceram mesmo com a delimitação dos 299 casos.

5. Observou-se em trabalho mais amplo que 154/299 dos agentes são oriundos de "famílias de políticos" nos seus estados de atuação. Especificamente sobre a reprodução de "elites mineiras" em posições de poder no decorrer do Império e da República, ver Canêdo (2011).

6. Conforme afirma Sorá a Livraria Católica desempenhou a tarefa de integração do Centro Dom Vital, congregando o denominado "círculo católico". Segundo o autor: "Mais do que por uma intenção doutrinário-religiosa, esse grupo era unido por uma rejeição visceral à República Velha, e à intenção de introduzir o 'social' na produção intelectual. O renome acumulado pelo conjunto de seus integrantes formou uma rede de relações também utilizada para promover atividades de edição" (2010:123).

7. Sínteses biográficas de Afrânio de Melo Franco e Virgílio, assim como do próprio Afonso Arinos, podem ser conferidas em http: / / cpdoc.fgv.br/producao/dossies / AEraVargas1/biografias.

8. As publicações de Afonso Arinos relacionadas a esse período estão listadas nas referências bibliográficas.

9. O rompimento de Afrânio de Melo Franco e Virgílio com Getúlio Vargas fora motivado pela não indicação deste último ao cargo de intendente de Minas Gerais.

10. Para uma comparação das diferentes "coleções" denominadas "brasilianas" existentes no período em distintas editoras, ver Sorá (2010).

11. Como demonstra Lattman-Weltman, o pai de Afonso Arinos, Afrânio de Melo Franco, encarnava, ao lado de outros "ilustres", a figura do estadista e os traços do homem público que o filho idealizava. Ele recorria ao gênero panegírico (biografias históricas) e o utilizava com grande aptidão para reconstrução biográfica, conseguindo "o resgate de uma época e de uma herança, a construção de uma linhagem, a valorização de uma tradição e, por fim, mas não menos importante, a definição de uma identidade tanto individual quanto coletiva" (2005:37).

12. Gustavo Sorá chega a localizar Afonso Arinos como "parte do sistema de parentesco prático que rodeou a vida do editor [José Olympio] e sua família nuclear" (2010:445), 
ou seja, membro da "casa" ou da "grande família" privilegiado pela proximidade e pelo afeto dispensado por José Olympio ("o patriarca").

13. Tendo à frente Francisco Campos, que então presidia o recém-criado Ministério da Educação e Saúde Pública, a reforma se orientava pela busca de "modernização" e formação de "profissionais qualificados". Com essa base, foi promulgado o Estatuto das Universidades Brasileiras (1931), foram criadas a Universidade de São Paulo (1934) e a Universidade do Rio de Janeiro (1935), embrião da Universidade do Brasil (1937), e foi constituído o Conselho Nacional de Educação (Fávero, 2006).

14. Vale ressaltar que, relativamente ao universo de 299 investigados na pesquisa sociográfica, a maior presença é a de advogados (170) e a instituição de ensino superior é a UFRJ (50); estando os agentes com títulos universitários em economia (28) e a USP (36), como IES (Instituições de Ensino Superior), nos terceiros lugares. Os perfis de Arinos e Delfim se coadunam, portanto, com as formações dominantes no quadro geral.

15. Luiz de Freitas Bueno nasceu em 1919 no interior de São Paulo (Cravinhos). Formado em Ciências e Letras e engenheiro elétrico, realizou o doutorado e obteve a livredocência em estatística econômica pela Universidade Federal do Rio Grande do Sul. Na década de 1940 entrou para a FEA-USP, como professor de estatística, e tornou-se catedrático. É apresentado no portal da instituição como "praticamente autodidata nessa ciência, que chegava tardiamente ao Brasil". Na sua biografia de professor emérito, é destacado que teria "provocado significativos avanços na faculdade por seu pioneirismo na difusão e no exercício da econometria. Formou muitos discípulos, entre os quais Delfim Netto e Affonso Celso Pastore, principalmente porque trabalhou diretamente com eles. Foi Bueno quem introduziu a prática de contratação de ex-alunos para o cargo de assistentes, exemplo seguido até os dias de hoje" (disponível em http:/ / www.fea.usp.br. Acessado em outubro de 2012).

16. Raul Pilla foi médico e político no Rio Grande do Sul. Professor universitário da Faculdade de Medicina de Porto Alegre, ocupou cargos eletivos como os de deputado estadual e federal (entre 1946 e 1967) e foi dirigente partidário do Partido Federalista e do Partido Libertador. Escreveu dezenas de livros.

17. Lattman-Weltman (2005) demonstra em detalhes como Getúlio Vargas assumia nos escritos e nos discursos de Afonso Arinos, produzidos entre 1946 e 1954, a figura do "caudilho", representando a antítese dos heróis destacados por intermédio do gênero panegírico. Após o suicídio do presidente, todavia, Arinos teria privilegiado a crítica ao "caudilhismo" como sistema marcado pelo clientelismo, paralisia governativa e crise da institucionalidade política.

18. Sobre as semelhanças e as diferenças entre as posições acerca do "liberalismo" de Afonso Arinos e Carlos Lacerda no que se convencionou chamar de "udenismo", ver o recente artigo de Chaloub (2013). Na sua ótica, Arinos professava um "udenismo pedagógico", "o qual julga negativamente o conflito e atribui às elites o papel de, sobranceiramente, mediá-lo", ao passo que Carlos Lacerda é associado ao "udenismo conflitivo" que "insere as elites no enfrentamento político, toma o confronto com o inimigo como essência do embate político" (ibidem:295-296).

19. As publicações de Afonso Arinos relacionadas a esse período estão listadas nas referências bibliográficas. 


\section{Eliana Tavares dos Reis e Igor Gastal Grill}

20. Tomando-se o cruzamento realizado no exame de 299 casos entre gêneros de escrita versus década de ingresso na carreira eletiva, é possível ratificar que os agentes examinados são representativos de regularidades e discrepâncias mais gerais. Encontrou-se, entre aqueles que ingressaram na década de 1930, 20 agentes dedicados predominantemente a publicações do tipo históricas, literárias e (auto)biográficas e 28 com produções setoriais e generalistas; para aqueles que ingressaram na década de 1960, para os primeiros gêneros o número diminuiu para apenas cinco casos, ao passo que para os últimos aumentou para 42 agentes.

21. A expressão foi inspirada na definição dada por Loureiro para caracterizar o segmento que adquiriu "destaque no seio das elites político-administrativas, fazendo-os ascender da condição de assessores técnicos à de dirigentes políticos" (1992:47).

22. Sobre as transferências culturais com os norte-americanos, a constituição de uma nova linguagem do poder e a legitimação de novos perfis de "especialistas" da política e da cultura, ver Dezalay e Garth (2000).

23. Foi reeditado em 2009 (Editora Unesp em parceria com Edições Facamp). Em apresentação de economista da FEA, o livro adquire o estatuto de "clássico sobre o assunto". A adjetivação se deve à contribuição acadêmica, sobretudo pela utilização pioneira de "recursos analíticos da teoria econômica", mesmo que ainda sem muita sofisticação econométrica (Macedo, 2001:376).

24. A FEA foi criada em 1946, justamente depois do Estado Novo e nos primórdios da Guerra Fria, período que marcou, por um lado, a decadência do modelo francês de estudos econômicos e, por outro, o forte investimento dos Estados Unidos na mobilização/formação/exportação de especialistas do mundo inteiro nas áreas de economia, matemática, física, engenharia e outras especialidades, oferecendo-lhes condições de pesquisas e de integração nas universidades. Os investimentos governamentais e norte-americanos nesta e em outras instituições de ensino e pesquisa foram sistemáticos na segunda metade dos anos 1960.

25. Disponível em http:/ /www.fea.usp.br/feaecon / / perfilãex.php?i=\&u=22\&e=6, acessado em 5/7/2013.

26. Perissinotto (2012) e Loureiro, Olivieri e Martes (2010) retomaram de forma fecunda alguns dos principais trabalhos que relacionaram burocracia e política no Brasil, tanto em momentos de autoritarismo como de democracia.

27. É possível afirmar que Delfim Netto é um caso desviante do provável. Suas características sociais, escolares e estéticas podem estar na base de resistências e estigmatizações das quais foi alvo, sobretudo lançadas pelas elites estabelecidas na sua estreia no cenário público. Ver Grün (2014).

28. As publicações de Delfim Netto estão listadas nas referências bibliográficas deste artigo.

29. Expressão cunhada por Gilberto Freyre e que inspirou o trabalho de Tatyana Maia (2012).

30. Quintella (1984) também apontou para fatores de coesão e unidade entre os integrantes do Conselho Federal de Cultura. Tal homogeneidade também é perceptível na Academia Brasileira de Letras e no Instituto Histórico e Geográfico Brasileiro. A recorrência dos mesmos nomes nestas três instituições (CFC, ABL e IHGB); os termos carregados de afetividade, intimidade e proximidade que são acionados nos discur- 
sos realizados pelos seus membros; assim como os requisitos informais (identidade regional, formação intelectual, convivências, cargos políticos, missão para a cultura etc.) acionados para admissão no(s) grupo(s) permitiriam identificar um grupo ocupando a condição de elite cultural no Brasil naquele momento. Cabe lembrar que Afonso Arinos pertenceu às três instituições.

31. O lugar central ocupado pelo então ministro do Planejamento Delfim Netto e por outros economistas no "escândalo financeiro" do início da década de 1980 permite explorar lógicas que regiam as relações entre ocupantes de cargos de alto escalão do Poder Executivo, empresários e intermediários atuantes como assessores ou consultores com trânsito junto a órgãos governamentais. A cuidadosa descrição de Marcos Otávio Bezerra (1995) mostra como às qualificações técnicas e políticas atribuídas aos economistas somam-se o potencial de intermediação e de constituição de teias de relações no interior do campo burocrático, sobretudo como são passíveis de maximização enquanto trunfo político e para a ampliação da superfície de contatos e vínculos.

32. Novamente, pode-se enfatizar as correspondências encontradas no que diz respeito aos gêneros de escrita privilegiados no quadro mais amplo e nos dois casos exemplares no tocante à polarização entre produções escritas generalistas ou encobrindo gêneros variados entre diplomados em Direito (Arinos), em um extremo, e produções setorializadas associadas aos formados em Economia (Delfim), no outro. Ver Grill e Reis (2012).

33. Visando apontar alguns indícios no sentido de apreender a estrutura interna do espaço dos think tanks nos EUA, Tom Medvetz (2008) pondera que os mesmos fatores que levam esses agentes a ocupar uma posição central no campo do poder são responsáveis por sua vulnerabilidade frente às diferentes áreas que são articuladas na constituição dessa figura híbrida. Neste caso, a discussão entre heteronomia em oposição à autonomia se complexifica, pois se está diante de múltiplas relações heterônomas (acadêmicas, políticas, econômicas...) que cortam esse universo, se cruzam e geram formas complexas.

34. Termos que foram inspirados nas análises de Dezalay e Garth (2000). 


\section{REFERÊNCIAS BIBLIOGRÁFICAS}

ABREU, Alzira et al. (orgs.). (2001), Dicionário Histórico-Biográfico Brasileiro Pós-30. Rio de Janeiro, FGV Editora.

ALONSO, Angela. (2002), Ideias em Movimento. A Geração de 1870 na Crise do Brasil-Império. Rio de Janeiro, Paz e Terra.

BEZERRA, Marcos Otávio. (1995), Corrupção. Um Estudo sobre Poder Público e Relações Pessoais no Brasil. Rio de Janeiro, Relume-Dumará.

BOURDIEU, Pierre. (1984), "La Delegation et le Fetichisme Politique”. Actes de la Recherche en Sciences Sociales, nos 52-53, pp. 49-55.

BUCLET, Benjamin. (2009), “Os Peritos Não Governamentais da Biodiversidade Amazônica e seus Financiadores Internacionais: Uma Parceria Desigual em torno de Interesses Comuns". Revista Pós Ciências Sociais, vol. 6, no 12, pp. 89-114.

CANÊDO, Letícia Bicalho. (2011), “O Capital Político Multiplicado no Trabalho Genealógico". Revista Pós Ciências Sociais, vol. 8, no 15, pp. 55-76.

CHALOUB, Jorge. (2013), “Dois Liberalismos na UDN: Afonso Arinos e Lacerda entre o Consenso e o Conflito". Revista Estudos Políticos, no 6, pp. 294-311.

CORADINI, Odaci Luiz. (2007), "Engajamento Associativo/Sindical e Recrutamento de Elites Políticas: 'Empresários' e 'Trabalhadores' no Período Recente no Brasil". Antropolítica, vol. 19, pp. 113-146.

. (2011), "Representação Política e de Interesses: Bases Associativas dos Deputados Federais de 1999 a 2011". Sociedade e Estado, vol. 26, pp. 197-220.

COSTA, Luiz Domingos e CODATO, Adriano. (2013), "Profissionalização ou Popularização da Classe Política Brasileira? Um Perfil dos Senadores da República”, in A. Marenco (org.), Os Eleitos: Representação e Carreiras Políticas em Democracia. Porto Alegre, Editora da UFRGS, pp. 107-134.

DEZALAY, Yves e GARTH, Bryant. (2000), “A Dolarização do Conhecimento TécnicoProfissional do Estado: Processos Transnacionais e Questões de Legitimação na Transformação do Estado (1960-2000)". Revista Brasileira de Ciências Sociais, vol. 15, noㅡ 43, pp. 163-175.

FÁVERO, Maria de Lourdes. (2006), “A Universidade no Brasil: Das Origens à Reforma Universitária de 1968”. Educar, № 28, pp. 17-36.

GARCIA JR., Afrânio. (1993), “Les Intellectuels et la Conscience Nationale au Brésil”. Actes de la Recherche en Sciences Sociales, no 98, pp. 2-33.

GRILL, Igor Gastal. (2008), "Processos, Condicionantes e Bases Sociais da Especialização Política no Rio Grande do Sul e no Maranhão". Revista Sociologia e Política, vol. 16, no 30, pp. 65-87.

. (2013), "Especialização Política: Bases Sociais, Profissionalização e Configurações de Apoios", in E. Seidl e I. G. Grill (orgs.), As Ciências Sociais e os Espaços da Política no Brasil. Rio de Janeiro, FGV Editora, pp. 227-278. 
e REIS, Eliana Tavares dos. (2012), “O Que Escrever quer Dizer na Política? Carreiras Políticas e Gêneros de Produção Escrita”. Revista Pós Ciências Sociais, vol. 9, no 17, pp. 101-121.

GRÜN, Roberto. (2014), “Algumas Intersecções Não-intuitas entre o Mundo da Cultura, da Política e da Economia no Brasil Contemporâneo", in E. T. dos Reis e I. G. Grill (orgs.), Estudos sobre Elites Políticas e Culturais. São Luís, Editora da UFMA, pp. 101-148.

GUILHOT, Nicolas. (2001), “Les Professionnels de la Démocratie. Logiques Militantes et Logiques Savantes dans le Nouvel Internationalisme Américain". Actes de la Recherche en Sciences Sociales, no 139, pp. 53-65.

LATTMAN-WELTMAN, Fernando. (2005), A Política Domesticada: Afonso Arinos e o Colapso da Democracia em 1964. Rio de Janeiro, FGV Editora.

LOUREIRO, Maria Rita. (1992), "Economistas e Elites Dirigentes no Brasil”. Revista Brasileira de Ciências Sociais, no 20, pp. 45-65.

. (1997), Economistas no Governo: Gestão Econômica e Democracia. Rio de Janeiro, FGV Editora.

; OLIVIERI, Cecília; MARTES, Ana Cristina. (2010), “Burocratas, Partidos e Grupos de Interesse: O Debate sobre Política e Burocracia no Brasil”, in M. Loureiro; F. Abrucio e R. S. Pacheco (orgs.), Burocracia e Política no Brasil. Rio de Janeiro, FGV Editora, pp. 73-108.

MACEDO, Roberto. (2001), “Antônio Delfim Netto”. Estudos Avançados, vol.15, no 43, pp. 375-385.

MAIA, Tatyana de A. (2012), Os Cardeais da Cultura Nacional: O Conselho Federal de Cultura na Ditadura Civil-Militar (1967-1975). São Paulo, Itaú Cultural/Iluminura.

MARENCO, André. (2001), "Sedimentação de Lealdades Partidárias no Brasil: Tendências e Descompassos". Revista Brasileira de Ciências Sociais, vol. 6, no 45, pp. 69-83.

e SERNA, Miguel. (2007), "Por que Carreiras Políticas na Esquerda e na Direita não São Iguais? Recrutamento Legislativo em Brasil, Chile e Uruguai". Revista Brasileira de Ciências Sociais, vol. 22, pp. 93-113.

MARTINS, Carlos Benedito. (2009), “A Reforma Universitária de 1968 e a Abertura para o Ensino Superior Privado no Brasil”. Educação \& Sociedade, vol. 30, no 106, pp. 15-35.

MEDVETZ, Thomas. (2008), “Think Tanks as an Emergent Field”. Social Science Research Council, outubro, pp.1-10.

MENEGUELLO, Rachel. (1998), Partidos e Governos no Brasil Contemporâneo (1985-1987). Rio de Janeiro, Paz e Terra.

MICELI, Sergio. (1979), Intelectuais e Classe Dirigente no Brasil (1920-1945). Rio de Janeiro, Difel.

. (1981), “Carne e Osso da Elite Política Brasileira Pós-30”, in B. Fausto (org.), História Geral da Civilização Brasileira: O Brasil Republicano. Sociedade e Política (1930-1964). São Paulo, Difel, pp. 557-596.

OFFERLÉ, Michel. (1996), “Entrées en Politique”. Politix, no 35, pp. 3-5.

DADOS - Revista de Ciências Sociais, Rio de Janeiro, vol. 58, n’o 2, 2015 


\section{Eliana Tavares dos Reis e Igor Gastal Grill}

PÉCAUT, Daniel. (1990), Os Intelectuais e a Política no Brasil, entre o Povo e a Nação. São Paulo, Ática.

PERISSINOTTO, Renato. (2012), "Burocracia Econômica e Industrialização no Brasil (1930-1966): Notas para uma Futura Comparação com o Caso Argentino". Anais do 36o Encontro Anual da Anpocs, 21-25 de outubro, Águas de Lindóia, SP.

e MIRÍADE, Angel. (2009), "Caminhos para o Parlamento: Candidatos e Eleitos nas Eleições para Deputado Federal em 2006". DADOS - Revista de Ciências Sociais, vol. 52, no 2, pp. 301-333.

PHELIPPEAU, Erik. (2002), L'Invention de l'Homme Politique Moderne. Paris, Bélin.

POLITIX. (2004), “Dossier: Trajectoires de la Notabilité", vol. 17, no 67, pp. 3-7.

PONTES, Heloísa. (1988), "Retratos do Brasil: Um Estudo dos Editores, das Editoras e das 'Coleções Brasilianas', nas Décadas de 1930, 40 e 50". Boletim Informativo e Bibliográfico (BIB), no 26, pp. 56-89.

QUINTELLA, Maria M. Diegues. (1984), “Cultura e Poder ou Espelho, Espelho Meu: Existe Alguém mais Culto do que Eu?", in S. Miceli (org.), Estado e Cultura no Brasil. São Paulo, Difel, pp. 113-135.

REIS, Eliana Tavares dos. (2008), “Da Contestação à Profissionalização Política: Capital Militante, Capital Social e Capital Político", in I. G. Grill; E. T. dos Reis e J. Barros Filho (orgs.), Elites, Profissionais e Lideranças Políticas: Pesquisas Recentes. São Luís, Editora da UFMA, pp. 83-170.

. (2013), “Saberes em Movimento: Transações entre 'Intelectuais', Definições de Ciências Sociais e a 'Política'", in E. Seidl e I. G. Grill (orgs.), As Ciências Sociais e os Espaços da Política. Rio de Janeiro, FGV Editora, pp. 21-74.

e GRILL, Igor Gastal. (2008), “Letrados e Votados: Lógicas Cruzadas do Engajamento Político no Brasil”. Tomo, vol. 13, pp. 127-168.

RODRIGUES, Caio Farah e FALCÃO, Joaquim. (2005), “O Projeto da Escola de Direito do Rio de Janeiro". Cadernos FGV Direito Rio, Texto para Discussão no 1, pp. 4-15.

RODRIGUES, Leôncio Martins. (2002), "Partidos, Ideologia e Composição Social". Revista Brasileira de Ciências Sociais, vol. 17, pp. 31-47.

SANTOS, Fabiano G.M. dos e PEGURIER, Fabiano. (2011), “Political Careers in Brazil: Long-term Trends and Cross-sectional Variation". Regional \& Federal Studies, vol. 21, no 2, pp. 165-183.

SORÁ, Gustavo. (2010), Brasilianas. José Olympio e a Gênese do Mercado Editorial Brasileiro. São Paulo, Edusp.

WEBER, Max. (1987), Economía y Sociedad. México, Fondo de Cultura Económica. 


\section{Publicações de Afonso Arinos de Melo Franco}

MELO FRANCO, Afonso Arinos de. (1936), Conceito de Civilização Brasileira. São Paulo, Companhia Editora Nacional, Coleção Brasiliana.

. (1937), O Índio Brasileiro e a Revolução Francesa: As Origens Brasileiras da Teoria da Bondade Natural. Rio de Janeiro, José Olympio.

. (1937), Roteiro Lírico de Ouro Preto. (1a edição, publicado como Boletim da Sociedade Fellipe D'Oliveira, com ilustrações de Pedro Nava).

. (1937), Espelho de Três Faces. São Paulo, Edições e Publicações Brasil. (Um conjunto de ensaios, crônicas e perfis).

. (1938), Síntese da História Econômica do Brasil. Rio de Janeiro, Serviço Gráfico/Ministério da Educação e Saúde.

• (1939), Terra do Brasil. São Paulo, Companhia Editora Nacional. (Livro de História).

. (1939), Idéia e Tempo. Rio de Janeiro, Editora Moderna. (Crônica e crítica).

(1942), Um Soldado do Reino e do Império: A Vida do Marechal Calado. Rio de Janeiro, Gráfica Laemmert.

. (1944), Homens e Temas do Brasil. Rio de Janeiro, Livraria e Editora Zélio Valverde.

. (1944), Mar de Sargaço. São Paulo, Livraria Martins.

(1945), Portulano. São Paulo, Livraria Martins.

. (1947), História do Banco do Brasil - Primeira Fase: 1808-1835. São Paulo, Associação

Comercial de São Paulo.

. (1955), Um Estadista da República. Rio de Janeiro, José Olympio.

(1956), Barra do Dia. Rio de Janeiro, Editora Simões (livro de poesias).

. (1957), Episódios de História Contemporânea. Rio de Janeiro, Forense.

(1957), Pela Liberdade de Imprensa. Rio de Janeiro, José Olympio.

(1958), Curso de Direito Constitucional. Rio de Janeiro, Forense. Vol. 1.

. (1958), Síntese da História Econômica do Brasil. (2a ed.). Rio de Janeiro, Progresso.

(1960), Curso de Direito Constitucional. Rio de Janeiro, Forense. Vol. 2.

. (1961), A Alma do Tempo - Formação e Mocidade. Rio de Janeiro, José Olympio. (Primeiro volume de suas memórias).

e PILLA, Raul. (1958), Presidencialismo ou Parlamentarismo. Rio de Janeiro, José Olympio.

\section{Publicações de Antônio Delfim Netto}

DELFIM NETTO, Antônio. (1966), Problemas Econômicos da Agricultura Brasileira. São Paulo, Universidade de São Paulo.

. (1966), "Agricultura e Desenvolvimento no Brasil". Estudos ANPES, no 5.

(1966), Planejamento para o Desenvolvimento Econômico. São Paulo, Pioneira.

DADOS - Revista de Ciências Sociais, Rio de Janeiro, vol. 58, n’o 2, 2015 


\section{Eliana Tavares dos Reis e Igor Gastal Grill}

. (1967), Estudo de Educação Econômico-social do Brasil. São Paulo, Instituto de Sociologia e Política da Federação do Comércio do Estado de São Paulo.

_ (1967), Política Econômica e Financeira do Governo: 1967/68. São Paulo, FEA-USP. e PINTO, Carlos Alberto de A. (1966), "Café do Brasil: Vinte Anos de Substituição no Mercado Internacional". Estudos ANPES, no 3.

e PINTO, Carlos Alberto de A. (1967), O Café no Brasil. São Paulo, Ministério da Indústria e do Comércio, Instituto Brasileiro do Café e Assessoria de Relações Públicas.

et al. (1965), "Alguns Aspectos da Inflação Brasileira". Estudos ANPES, no 1. 


\section{RESUMO}

Trajetórias de Multinotabilidades: Reconfigurações Históricas e

Condicionantes Sociais das Inscrições Politicas e Culturais de

Parlamentares Brasileiros

O artigo discute os condicionantes da afirmação de parlamentares, indissociavelmente em domínios do poder político e da produção cultural no Brasil. Para a apreensão de lógicas e práticas que presidem a ocupação de posições variadas e relativamente bem alocadas no Parlamento, em universidades, nas burocracias estatais, na mídia, em instâncias de consagração intelectual e em arenas de formulação de problemáticas políticas, o foco recai sobre o estudo das trajetórias consideradas exemplares de Afonso Arinos e Delfim Netto. Os percursos seguidos e os posicionamentos assumidos pelos agentes são examinados à luz das conjunturas históricas, das reconfigurações nas relações de poder (no plano nacional e internacional) e das transformações nos planos do ensino universitário e da mediação cultural. Pondera-se sobre redefinições e amálgamas dos repertórios legítimos de intervenção (erudição letrada e conhecimento técnico) mobilizados nos principais debates sobre a nação ao longo do século XX. Isso, por sua vez, permite, por um lado, identificar processos, espaços, competências e linguagens que são concorrentes, complementares e interdependentes, e, por outro, refletir acerca do trabalho de elaboração de representações sobre a cultura, a política, a economia e o Estado.

Palavras-chave: elites; intelectuais; política; trajetórias; cultura

\section{ABSTRACT \\ Multi-notability Trajectories: Historical Reconfigurations and Social Determinants of the Political and Cultural Inscription of Brazilian Congressmen}

This article discusses the determinants of the affirmation of congressmen, which cannot be disassociated from the realms of political power and cultural production in Brazil. In order to apprehend the logics and practices that preside over the occupations over varied and relatively well allocated positions in Parliament, universities, state bureaucracies, media, intellectual legitimation spaces and arenas in which political issues are formulated, the authors focus on the study the exemplary trajectories of Afonso Arinos and Delfim Netto. The trajectories and positions occupied by these figures are examined in light of historical conjunctures, the reconfiguration of power relations (at the national and international levels) and the transformations in 
the domains of university education and cultural mediation. The redefinitions and amalgamations of legitimate repertoires of interventions (erudition and technical knowledge) mobilized in the main debates concerning the nation in the twentieth century are considered. This, in turn, allows for, on one hand, the identification of processes, spaces, competences and languages that are concurrent, complementary and interdependent, and, on the other one, reflect upon the elaboration of representation of culture, politics, the economy and the State.

Keywords: elites; intellectuals; politics; trajectories; culture

\author{
RÉSUMÉ \\ Trajectoires de Multi-notabilités: Reconfigurations Historiques et \\ Conditionnements Sociaux des Inscriptions Politiques et Culturelles des \\ Parlementaires Brésiliens
}

Cet article analyse les facteurs conditionnant l'affirmation de parlementaires dans les domaines indissociables du pouvoir politique et de la production culturelle au Brésil. Pour mieux comprendre les logiques et pratiques qui président à l'occupation de diverses positions de choix au Parlement, dans les universités, les bureaucraties étatiques, les médias, les instances de consécration intellectuelle et les espaces de formulation des problématiques politiques, nous étudierons plus spécifiquement les trajectoires, considérées comme exemplaires, d'Afonso Arinos et de Delfim Netto. Les parcours suivis et les positions assumées par ces agents seront examinés à la lumière des conjonctures historiques, des reconfigurations des rapports de pouvoir (aux plans national et international) et des transformations de l'enseignement universitaire et de la médiation culturelle. Seront abordés les redéfinitions et les amalgames des répertoires légitimes d'intervention (érudition lettrée et connaissances techniques) mobilisés dans les principaux débats sur la nation au long du XXème siècle. Cela permettra d'un côté d'identifier des processus, espaces, compétences et langages concurrents, complémentaires et interdépendants, et de l'autre de mener une réflexion sur le travail d'élaboration des représentations sur la culture, la politique, l'économie et l'État.

Mots-clés: élites; intellectuels; politique; trajectoires; culture 


\section{RESUMEN}

Trayectorias de Multi-notabilidades: Reconfiguraciones Históricas y Condicionantes Sociales de las Inscripciones Políticas y Culturales de Parlamentarios Brasileños

El artículo discute los condicionantes de la afirmación de parlamentarios en los indisociables dominios de poder político y producción cultural en Brasil. Para la aprehensión de lógicas y prácticas que presiden la ocupación de posiciones diversas y relativas bien ubicadas en el Parlamento, en las universidades, en las burocracias estatales, en los medios, en las instancias de consagración intelectual y en arenas de formulación de problemáticas políticas, el foco del análisis recae en el estudio de dos trayectorias consideradas ejemplares: Afonso Arinos y Delfim Netto. Los recorridos seguidos y las posiciones asumidas por los agentes son examinadas a partir de las coyunturas históricas, las reconfiguraciones en las relaciones de poder (en el plano nacional e internacional) y las transformaciones en los planos de la enseñanza universitaria y de la mediación cultural. Las redefiniciones y las amalgamas de los repertorios legítimos de intervención (erudición letrada y conocimiento técnico) movilizados en los principales debates sobre la nación a lo largo del siglo XX son discutidos. Eso permite, por un lado, identificar procesos, espacios, competencias y lenguajes concurrentes, complementares e interdependientes; y, por otro lado, reflexionar sobre el trabajo de elaboración de representaciones sobre la cultura, la política, la economía y el Estado.

Palabras clave: elites; intelectuales; política; trayectorias; cultura 


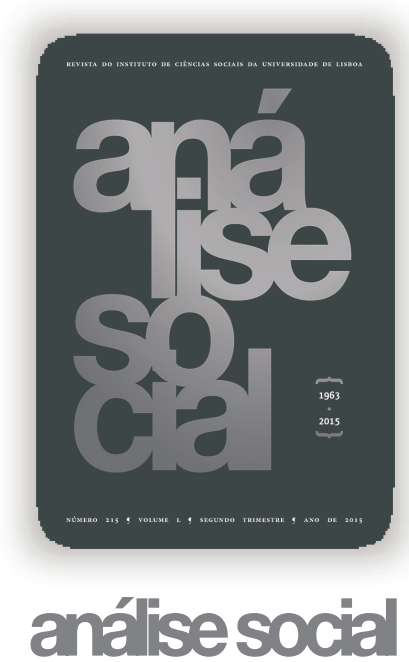

$215, \mathrm{~L}\left(2 .^{\circ}\right), 2015$

DIRETOR

José Manuel Sobral

EDIÇÃO E PROPRIEDADE

Instituto de Ciências Sociais da Universidade de Lisboa.

Av. Professor Aníbal

de Bettencourt, 9

1600-189 Lisboa Portugal

Tel. +351217804700

ASSINATURAS E VENDAS

Clara Cabral

Tel. +351217804761

analise.social@ics.ulisboa.pt

www.analisesocial.ics.ul.pt

\section{ARTIGOS}

A formação dos geólogos

João Freire, Pedro Pacheco, Luísa Veloso,

Raquel Rego e Telmo Clamote

A interferência do utilizador na produção

Pedro Xavier Mendonça e José Luís Garcia

Questões éticas e paradoxo do observador nos atendimentos de ação social

Adriano Duarte Rodrigues e Michel Binet

Governança territoral:

do debate teórico à avaliação da sua prática Valdir Roque Dallabrida

DOSSIÊ

ESTRUTURAS SOCIAIS, VALORES, SOCIABILIDADES

Desigualdade de rendimento

no Alentejo do Antigo Regime

Carlos Mendes Faísca e Bruno Lopes

D. Francisco de Melo Manuel da Câmara (1626-1678)

Susana Varela Flor

As touradas no Rio de Janeiro

do século XIX (1840-1852)

Victor Andrade de Melo

ENTREVISTA

José Mariano Gago,

estudante e dirigente associativo

por Luísa Tiago de Oliveira

RECENSÕES

\section{O BITUÁRIOS}

José Mariano Gago (1948-2015)

por José Manuel Sobral 